\title{
Extending Access, Choice, and the Reign of the Market: Higher Education Reforms in British Columbia, 1989-2004
}

\author{
JOHN D. DENNISON \\ University of British Columbia \\ HANS G. SCHUETZE \\ University of British Columbia
}

\section{ABSTRACT}

British Columbia has implemented two significant higher education reforms in the last 15 years. The first was an Access for All policy, and in particular, the creation of a new breed of institution-university colleges - and recognition of the right of colleges and institutes to confer "applied" degrees. The second reform, more recent and potentially with wider effect, is the decision to allow and, in fact, encourage the emergence of a private higher education sector to complement and to compete with the public sector. Although both reforms had the declared objective of enhancing accessibility and choice by expanding opportunities to study for degrees, the more recent one, now being implemented, had the further objective of opening higher education to market forces. 


\section{RÉSUMÉ}

La Colombie-Britannique a mis en oeuvre deux réformes principales de l'enseignement supérieur au cours des quinze dernières années. La première des deux, "Access for All," fut marquée par la création de nouvelles entités administratives dans la province que sont les collèges universitaires, et en même temps, l'octroi aux collèges communautaires et aux instituts d'études appliquées du droit de décerner des grades de 2e cycle. Une seconde réforme, plus récente et vraisemblablement plus significative au sens large, crée un secteur privé d'enseignement post-secondaire, voué à la complémentarité vis-à-vis du public, mais franchement compétitif. Les deux réformes ont comme objectif un niveau d'accès accru au système, avec au surplus une plus grande disponibilité des programmes d'études. La deuxième cache pourtant un but à venir qui est de rendre l'enseignement supérieur beaucoup plus susceptible aux forces du marché libre.

\section{INTRODUCTION}

Since the end of World War II, Canadian higher education has changed almost beyond recognition (Cameron, 1991). Reform has been continuous in every aspect of the higher education enterprise, in organization, management, curriculum, accessibility, and finance. Much of this has been viewed as improvement, more particularly, as steps towards a more democratic, accessible, and responsive system (Schuetze, 2002). But change is never without critics. Some have bemoaned the deterioration of academic standards and the diminished value of diplomas and degrees. Others, although acknowledging the value of representative participation in the governing structure of universities, have decried inevitable delays in decision making brought on by multiplication of bureaucracy and resulting pressure for effective management.

We here discuss significant developments in post-secondary education in British Columbia during the past decade, especially policies aimed at widening access to degree programmes and, more recently, opening higher 
education to private providers. If public-system reform was intended to increase access - with the help of new kinds and quantities of institutions, degrees, and programmes - then the new pro-market Liberal government taking office in May 2002 aimed primarily at opening higher education to the private sector.

We map these changes and analyze them with regard to impact, already manifest or to be expected, on student access and choice on the one hand, and quality on the other. Before dealing with the situation in British Columbia, we turn to developments in Canada's post-secondary education system overall, beginning with a brief note on the historical roots of the present system.

\section{DEVELOPMENTS IN POST-SECONDARY EDUCATION IN CANADA}

Canadian higher education has roots in British and French traditions, in a nation in a continent where the United States is the primary environmental influence (Axelrod, 1995). Nowhere is this convergence of environmental factors more evident than in the protocols and practices of post-secondary education in Canada.

Politically, Canada is a federal system in which the constitution, enacted in 1867 and revised in 1982, provides for distribution of powers between the national government and its ten provinces. Although conscious of the need for strong central authority in essential arenas such as defence and trade, the architects of confederation were equally sensitive to regional diversity in religious, socio-cultural, and linguistic traditions. Hence education, broadly defined, was placed under the jurisdiction of provincial governments. At present, post-secondary education, with some variation in range and scope in each province, broadly encompasses a university and a non-university sector, although the latter involves considerably diversity (Dennison \& Gallagher, 1986; Gallagher, 1990; see also Jones, 1997).

In the first two decades after World War II, Canada had few universities, public or denominational, along with several academically-oriented twoyear colleges, mostly in Quebec and under secular control. The student 
population was drawn from a selected cohort of the population comprising fewer than ten percent of college-aged persons. These institutions were modeled largely on the structures, traditions and values of British and French universities.

Degree programmes were mainly in Arts, Science, and selected "professional" areas-Commerce, Medicine, Law, Agriculture, with a very few graduate degrees. Universities were often referred to as "elitist," despite the opening at War's end, when large numbers of war veterans were admitted with federal government support.

Dramatic reforms in the 1960 s, however, came to post-secondary education when it became apparent a "tidal wave" of students was about to seek advanced education. In response to this dramatic increase in social demand, new universities were constructed, capacity in established institutions increased, church related universities submitted to public ownership, and new faculty recruited in massive numbers. New degree programmes such as Education and Nursing appeared in areas beyond the traditional disciplines.

Accompanying these university reforms was an unprecedented expansion of the non-university system in the provinces. Business and industry pressed government to train better technicians if Canada was to compete in the international marketplace and no longer to rely upon skilled manpower imported from other countries to sustain industrial growth (Dennison \& Gallagher, 1986).

In response to demand, the federal government made large financial resources available to the provinces to construct and maintain an alternate system of post-secondary institutions, other than universities, to educate and train a workforce with the skills necessary to fill the industrial needs of the nation. This alternative system of institutions was given different names in various regions of Canada-community colleges, technical institutes, colleges of applied arts and technology, and in Quebec, CÉGEPs (Collèges d'enseignement général et professionnel). Although some of these new institutions offered academic programmes equivalent to the first two years 
of a university degree, the majority concentrated upon certificates and diplomas offering skills to equip graduates for the workplace.

Unlike universities, which were organized and managed under a common set of protocols in every region of the country, colleges had structures that took into account the economic, socio-cultural, and historical diversity characteristic of Canada (Dennison \& Gallagher, 1986). In the Western provinces, Alberta and British Columbia, the primary role of the colleges was to increase access to further education, particularly university level studies. In Ontario and the Atlantic provinces, where there were more universities, colleges were expected to train "job ready" graduates for business and the industrial marketplace. Academic studies were not a priority. Yet one feature of college systems common to all provinces was a policy of open access to adults who had not completed a high school diploma and who had been denied the opportunity to continue their education in the past (Schuetze, 2000). Programmes ranging from basic literacy and English as a second language to the first years of university studies attracted large numbers of older students anxious to earn credentials which would help them enter the job market.

In many respects, the colleges, in their role as alternative educational options to the universities, were successful. Student numbers were high, community support was impressive and employers sought graduates from the applied programme to meet their manpower needs. Students who had earned university level credits and later transferred to the universities to complete their degrees, demonstrated that a college education was an acceptable preparation for advanced studies.

In time, problems arose. Colleges were under direct government control and thus denied the managerial and fiscal independence enjoyed by universities. This management model left the impression that colleges were extensions of government and not "real" post-secondary institutions like the universities. Students commonly thought that the college credentials, diplomas, or certificates they earned after two or three years of intensive study were not equivalent to a university degree. A perception arose that, if 
in competition with a university graduate for "good" jobs and chances for promotion, a college student would be at a distinct disadvantage. Academic research (e.g. Allen, 1996) and reports by the media emphasized the labour market advantages of those holding university degrees.

Inevitably, there was pressure on governments to provide more seats in degree programmes as demand from prospective students grew and public interest intensified. The response by provincial governments in the 1990s was threefold. First, established universities were funded to increase capacity. Second, a number of new universities or university-like institutions were established. Finally, some non-university institutions in a few provinces were authorized to offer "applied" degree programmes. The latter was a clear departure from prior practice under which the term "degree" (as was the term "university") was protected so institutions other than universities could not grant degrees.

Government actions varied by province. In British Columbia, selected colleges in large rural areas extended their two-year academic diplomas into four year degrees in Arts, Sciences, Education, Nursing, and other conventional fields (Dennison, 1992; Wynn, 1993). Given this notable change in curriculum, these colleges, five in number, became "university colleges," an institutional hybrid hitherto virtually unknown in Canada., ${ }^{1,2}$

The concept of a post-secondary institution offering degrees and at the same time technical, vocational, and adult education programmes, was new to Canada. They defied clear definition: in one province they were labelled university colleges and in another, Institutes of Technology and Advanced Learning. Neither name seems fully satisfactory. Of greater consequence was the question of accreditation, the wish to be included in the degree granting community of institutions, previously dominated by traditional universities. As no formal path to accreditation exists for public institutions in Canada, the solution undoubtedly lies with the passage of time, student and faculty performance, and public support. A similar dilemma confronts those holding the "new" or "applied" degrees. Inevitably, graduates holding the new degrees will be under scrutiny. Again, 
time and the success of graduates in the universities and the workplace will ensure the credibility of the applied degrees just as their acceptance has been long assured in countries such as the UK, Germany, New Zealand and Europe, Australia, and other advanced societies.

Besides creating university colleges, British Columbia, Alberta, and Ontario authorized the granting of "applied degrees" by non-university tertiary institutions offering diplomas in such applied areas as Business, Health, and Applied Sciences. In Ontario, new designations were sought for those institutions permitted to grant degrees, that is, to Institutes of Technology and Advanced Learning. Some public confusion was inevitable (on which see the contribution by Jones in this volume).

Reforms did not stop there. In a climate of neo-liberal market-based philosophy, several provinces were laying the groundwork for making private provision an option, including free-standing private degreegranting institutions. The public system greeted this development with stiff opposition. In particular, public universities feared that, despite the claim by neo-liberal governments that no public funding would be allocated to private institutions, a private higher education sector would drain muchneeded resources from public institutions (see, for example, the position of the Council of Ontario Universities - COU, 2000). In spite of these reservations and protests, private sector higher education continues to grow (cf. the case of British Columbia).

Meanwhile, the federal government, whose lack of constitutional powers to regulate higher education directly confined it to selected initiatives in the fields of research, promotion, and student support, began to strengthen the research capacity of universities with the avowed objective of making the Canadian economy competitive in global markets. It re-established research funding at levels achieved before the massive cuts of the early 1990s, set up a foundation for innovation that allocated substantial funding for research infrastructure, funded a significant number of Canada research chairs in the universities, and struck an agreement with the Association of Universities and Colleges of Canada (AUCC) regarding further funding for university 
research and increased commercialization of research results (Government of Canada \& AUCC, 2002).

Turning now to higher education reforms in British Columbia, we shall discuss in more detail some of the changes enacted in the 1990s and again at the beginning of the new century.

\section{HIGHER EDUCATION REFORMS IN BRITISH COLUMBIA 1989-2004}

Changes in the 1990s in British Columbia's post-secondary education system have been substantial as compared to the rest of Canada (Schuetze \& Day, 2001), and have taken two major directions in the last decade-anda-half. The first aimed at expanding the public system through institutional differentiation, and the second had the objective of increasing capacity (as well as competition) by opening higher education to private degreegranting institutions.

\section{Reforms in the 1990s: Widening Access Through Expansion and Differentiation of the Public System}

Massive demand led to expansion of post-secondary education from 1988 to the late 1990s. A Provincial Access Committee, established in 1988, articulated this demand and translated it into broad, yet concrete, proposals for government action (Provincial Access Committee, 1988), embodied in the government's Access for All policy.

At the time, British Columbia had 21 public post-secondary institutions, of which three were universities, and 18 community colleges and institutes. The universities and the institutes had the mandate to serve students from the province as a whole, whereas community colleges generally aimed to serve their regions. These institutions and their distribution in the six regions of the province are shown in Table 1. 
Table 1

Public Post-Secondary Education Institutions in British Columbia in 1988

\begin{tabular}{|c|c|c|}
\hline Region & Universities & Colleges \& Institutes \\
\hline Lower Mainland & $\begin{array}{l}\text { - University of } \\
\text { BC } \\
\text { - Simon Frasier } \\
\text { University }\end{array}$ & $\begin{array}{l}\text { - Capilano College } \\
\text { - Douglas College } \\
\text { - Kwantlen College } \\
\text { - Vancouver Community } \\
\text { College } \\
\text { - British Columbia Institute of } \\
\text { Technology (BCIT) } \\
\text { - Emily Carr Institute of Art } \\
\text { and Design } \\
\text { - Justice Institute } \\
\text { - Fraser Valley College }\end{array}$ \\
\hline Vancouver Island & $\begin{array}{l}\text { University of } \\
\text { Victoria }\end{array}$ & $\begin{array}{l}\text { - Malaspina College } \\
\text { - Camosun College } \\
\text { - North Island College }\end{array}$ \\
\hline Northern BC & & $\begin{array}{l}\text { - College of New Caledonia } \\
\text { - Northwest Community } \\
\text { College } \\
\text { - Northern Lights College }\end{array}$ \\
\hline Cariboo/Chilcotin & & - Cariboo College \\
\hline Okanagan & & - Okanagan College \\
\hline Kootenays & & $\begin{array}{l}\text { - Selkirk College } \\
\text { - East Kootenay Community } \\
\text { College }\end{array}$ \\
\hline
\end{tabular}

* The Open Learning Agency and its units (Open University, Open College and Knowledge Network) are not listed as they operate province-wide, and on a different operational base.

Source: Schuetze \& Day, 2001

The Canadian Journal of Higher Education Volume XXXIV, No. 3, 2004 
There has been a strong concentration of institutions in two regions, the Lower Mainland and the southern part of Vancouver Island and no degreegranting institution was found outside these two regions. Prospective students who lived elsewhere in the province and aspired to earn a degree had to relocate to one of the two metropolitan areas. Worse, there were too few places in the three universities to satisfy growing demand for programmes leading to academic degrees. Unlike most other Canadian provinces, including Ontario (see below), community colleges in British Columbia provided academic programmes equivalent to the first two years of degree studies. Many students, having completed a year or two in such a programme, could not afford the financial and social stress involved in a transfer to one of the three universities to complete their degree.

Overall, British Columbia trailed other provinces in participation rate of young people of traditional college age. It had relied overmuch on immigration to meet industrial demand for a well-educated and trained workers. This "strategy" led students, their parents, and their political representatives to exert pressure for reasonable access to degree programmes in the province. The Access for All report (Provincial Access Committee, 1988) and the ensuing policy of 1988 must be seen in this context.

In summary, the report recommended government action to:

- improve space and equipment in the post-secondary sector and enhance access to adult basic education throughout the province;

- strengthen and increase the number of second year university equivalent courses in community colleges throughout the province;

- establish a number of degree granting "university colleges." These institutions would be grafted administratively onto existing community colleges, and (initially) connected academically onto one of the existing universities;

- increase accessibility to post-secondary education for indigenous people (First Nations);

- increase accessibility to post-secondary education for people living in small and remote communities; and 
- establish and strengthen "open learning" systems as key mechanisms for meeting learning needs for people across the province.

These recommendations provided the substance of policy and operational initiatives by successive governments over the next decade. Government made multi-year commitments for system-wide increases in funding, for the establishment of a University of Northern British Columbia, and the creation of degree-granting university colleges in the Interior and on Vancouver Island (Cariboo, Okanagan, and Malaspina). It also increased capacity of universities and college academic transfer programmes.

Action was also taken to offer education to groups ill-served by the system. To improve access in small, remote communities, the Open Learning Agency opened.AProvincial Task Force on Native Post Secondary Education was commissioned. Budgets in adult special education grew, thus assisting people with disabilities (Schuetze \& Day, 2001). But the clear emphasis in Access for All was on additional resources to create more spaces in degree programmes and on establishing new types of institutions to satisfy demand for university-type education, that is, for studies leading to academic degrees.

The creation of three university colleges, at first, and upgrading of the status of these institutions, reinforced the latent "academic drift" among the colleges and institutes - the aspiration for degree-granting status. The university colleges began to re-interpret their missions, as did colleges and institutes, causing faculty, administrations, and boards of colleges to worry about the effects of "academic drift" on the original mission and emphasis of community colleges (Dennison, 1995). 
Table 2

Public Post-Secondary Education Institutions in British Columbia in 1998

\begin{tabular}{|c|c|c|c|}
\hline Region & Universities & $\begin{array}{l}\text { University } \\
\text { Colleges }\end{array}$ & Colleges \& Institutes \\
\hline $\begin{array}{l}\text { Lower } \\
\text { Mainland }\end{array}$ & $\begin{array}{l}\text { - University of } \\
\text { BC } \\
\text { - Simon Frasier } \\
\text { University } \\
\text { - Technical } \\
\text { University of } \\
\text { BC** }\end{array}$ & $\begin{array}{l}\text { - University } \\
\text { College of } \\
\text { the Fraser } \\
\text { Valley } \\
\text { - Kwantlen } \\
\text { University } \\
\text { College }\end{array}$ & $\begin{array}{l}\text { - Capilano College } \\
\text { - Douglas College } \\
\text { - Langara College } \\
\text { - Vancouver } \\
\text { Community } \\
\text { College } \\
\text { - British Columbia } \\
\text { Institute of } \\
\text { Technology (BCIT) } \\
\text { - Emily Carr Institute } \\
\text { of Art and Design } \\
\text { - Justice Institute } \\
\text { - Institute for } \\
\text { Indigenous } \\
\text { Government }\end{array}$ \\
\hline $\begin{array}{l}\text { Vancouver } \\
\text { Island }\end{array}$ & $\begin{array}{l}\text { - University of } \\
\text { Victoria } \\
\text { - Royal Roads } \\
\text { University** }\end{array}$ & $\begin{array}{l}\text { - Malaspina } \\
\text { University } \\
\text { College }\end{array}$ & $\begin{array}{l}\text { - Camosun College } \\
\text { - North Island } \\
\text { College }\end{array}$ \\
\hline $\begin{array}{l}\text { Northern } \\
\text { BC }\end{array}$ & $\begin{array}{l}\text { University of } \\
\text { Northern BC }\end{array}$ & & $\begin{array}{l}\text { - College of New } \\
\text { Caledonia } \\
\text { - Northwest } \\
\text { Community } \\
\text { College } \\
\text { - Northern Lights } \\
\text { Community } \\
\text { College }\end{array}$ \\
\hline
\end{tabular}




\begin{tabular}{|c|c|c|}
\hline Cariboo/ & - University & - Nicola Valley \\
\hline Chilcotin & $\begin{array}{l}\text { College of } \\
\text { the Cariboo }\end{array}$ & $\begin{array}{l}\text { Institute of } \\
\text { Technology }\end{array}$ \\
\hline Okanagan & $\begin{array}{l}\text { Okanagan } \\
\text { University } \\
\text { College }\end{array}$ & \\
\hline Kootenays & & $\begin{array}{l}\text { - Selkirk College } \\
\text { - College of the } \\
\text { Rockies }\end{array}$ \\
\hline
\end{tabular}

* The Open Learning Agency and its units (Open University, Open College and Knowledge Network) are not listed as they operate province-wide, and on a different operational base

** Degree-granting programmes in a small number of fields of study only. Source: Schuetze \& Day, 2001

Overall, the number of institutions increased from 21 to 28 . More importantly, the number of degree-granting institutions increased from three to a total of thirteen granting full, that is, four-year academic degrees. Although degree programme graduates at BCIT and the Emily Carr Institute for Art and Design were few, five university colleges enrolled and graduated increasing numbers of students. Similarly, the numbers of graduates from Royal Roads University, set up in 1995 as a niche institution to cater to professionals seeking applied and professional degree programmes, were small. The bulk of degree graduates continued to come from three established universities, the newest traditional university, UNBC, delivering an increasing share. ${ }^{3}$ During the decade from the inception of the Access for All policy, total FTE enrolment in universities, colleges, and institutes has been increased by approximately $42,000-$ an increase of almost 30 percent (Schuetze \& Day, 2001).

Building on the work of the 1990 s, the province embarked on a catchup to raise participation in post-secondary education, and particularly 
in higher education, to the level of other provinces. The system was diversified by adding University Colleges to the institutional fabric. As a result of all these measures, student numbers grew significantly. Even more significantly, the old binary system, by which only universities (and now also the new university colleges) could grant degrees, whereas colleges and institutes could not, gradually eroded as institutes came to award degrees, even if these were not "academic" but "applied" degrees.

As mentioned in the overview of the Canadian situation, both innovations, university colleges and applied degrees, were successful in producing more graduates, but did not fit well with the overall institutional system.

\section{Applied degrees}

The concept of "applied" degrees remained as vague as ever. Traditionally, universities had offered, together with Arts and Science, a wide range of "professional" (Commerce, Law, Dentistry, and so on) degrees. Although the concept of an "applied" degree has long been accepted in Europe and the United Kingdom, in Canada there had been no conceptual distinction between academic and professional degrees, even if there might have been a status gap between academic and applied studies.

To clarify the notion of the applied degree, the government of British Columbia (Ministry of Advanced Education, 1998) required that applied programmes:

- should link theory and practice and make clear the balance between the acquisition of employability skills and general education requirements; and

- must incorporate a practical component. This requirement can take many different forms such as: work experience, practice, projects, or field experience. This component is what distinguishes the degree from others which may have similar course context.

Time will tell whether the labour market will accept the new brand of applied degrees as equivalent to the traditional university degrees. 


\section{University colleges}

The credibility of degrees, particularly in academic and professional areas, is closely related to the credibility of the institution from which they are awarded. Public colleges and universities in Canada, unlike their counterparts in the United States, do not undergo a formal accreditation process, although many professional programmes are required to do so. However, for universities and other degree granting institutions, a quasi accreditation requirement exists in the form of the need to qualify for membership in the Association of Universities and Colleges (AUCC). This affiliation ensures mutual recognition of degrees awarded by one of the member institutions.

Although four of the five university colleges in British Columbia have successfully sought membership in AUCC, one (Kwantlen University College) has not and recent changes in criteria for admission make it unlikely, or at least much more difficult, for it to be admitted.

These new AUCC membership criteria postulate the following conditions which an applicant institution must meet (AUCC, 2003):

- [The institution] has an approved, clearly articulated and widely known and accepted mission statement and academic goals that are appropriate to a university and that demonstrate its commitment to: i) teaching and other forms of dissemination of knowledge; ii) research, scholarship, academic inquiry and the advancement of knowledge; and iii) service to the community

- it has as its core teaching mission the provision of education of university standard with the majority of its programmes at that level;

- it offers a full programme or programmes of undergraduate and/or graduate studies that animate its mission and goals, and that lead to a university degree or degrees conferred by itself or, if federated or affiliated with, or a constituent of a university, by the parent institution. Indicators will include:

- its undergraduate degree programmes are characterized by breadth and depth in the traditional areas of the liberal arts and/or sciences, and first degrees of a professional nature - such as medicine, law, 
teacher education, engineering - have a significant liberal arts and/ or sciences component;

- it has a proven record of scholarship, academic inquiry, and research; expects its academic staff to be engaged in externally peer reviewed research and to publish in externally disseminated sources; and provides appropriate time and institutional support for them to do so. Indicators of this commitment will include policies and programmes pertaining to the creation of knowledge, the development of curriculum, and the execution of research projects.

A careful assessment of these criteria will make it evident that an institution long committed to a comprehensive curriculum with a substantial number of students in adult basic education, vocational, trades, and technical programmes will have difficulties in making its case for admission. The same may be said of institutions which, although providing advanced training in specialized technologies, do not maintain an "academic" curriculum.

Another of the criteria established by AUCC as a requirement for membership is that the institution:

...has governance and an administrative structure appropriate to a university, including authority vested in academic staff for decisions affecting academic programmes including admissions, content, graduation requirements/standards, and related policies and procedures through membership on an elected academic senate or other appropriate elected body representative of academic staff (AUCC, 2003).

As a consequence of their history, and partly as a result of their relationship with the provincial government, colleges and institutes have been governed in a more authoritative and bureaucratic manner than universities. Faculty and staff involvement in decision making has been generally restricted to an advisory capacity. The board, with the advice of the president and his/her management team, has assumed final authority on all policies, fiscal and academic. In the last decade, legislation was introduced in British Columbia, whereby elected "education councils," 
with substantial membership of faculty and staff, have been given limited statutory authority over areas noted in the AUCC statement. As a result, all colleges and institutes in British Columbia now operate under a bi-cameral governance structure. Although this model is unique among non-university institutions in Canada, or indeed in North America, the question as to whether or not the existing bi-cameral system would be seen by AUCC as sufficient in meeting this requirement or require university colleges to adopt a true university-like governing model where academics have autonomous control over academic issues such as admission, programmes, curricula, and exams.

A related problem concerns the faculty of university colleges. Traditionally, the primary responsibility of faculty members in colleges and institutes has been teaching. Although research activity was not discouraged, there was no expectation that faculty undertake and publish research as a condition of employment, as it is for university faculty. If this is to change and faculty in university colleges must conduct research, then faculty recruitment, teaching loads, working conditions, and support structures will also have to change significantly. Thus, if university colleges are to adopt a university-like mandate and culture, it will require a major adjustment to the allocation of resources and careful selection of new faculty with respect to their potential for research productivity, in addition to their teaching qualifications. ${ }^{4}$

Despite difficulties in application, Access for All policy has not only advanced access and participation to higher education and especially degree level studies, it has also changed the higher education landscape in ways unprecedented in Canada.

\section{Reforms at the Beginning of the New Century: Opening Higher Education to the Market}

Private sector post-secondary education, both higher, i.e. degree granting, and non degree granting, is not entirely new to British Columbia. 


\section{The private training sector}

A private vocational training sector grew rapidly in the 1980 s. This sizable private training sector had been encouraged by Federal Government policy for a "free market" in federal training programmes. This development was supported by the provincial government, which probably saw competition from the private sector as having an effect on controlling increasing unit costs in the colleges and institutes. By 1990, there were over 1,000 Private Vocational Training Schools (PVTS) in British Columbia.

Although most PVTS are small, these now total over 1,200 in British Columbia, accommodating many thousands of learners (Gallagher \& Sweet, 1997). According to the Private Post Secondary Education Commission of British Columbia (PPSEC), during the academic year 1999/2000, the PVTSs in British Columbia accommodated some 190,000 learners, or approximately 60,000 students (expressed in FTEs, the public sector equivalencies). These private for-profit institutions are targeting prospective students not served, or inadequately served, by the public British Columbia post-secondary education system and who are willing and able to pay the fees. In most cases, these are considerably higher than those of public institutions.

When a new government came to power in British Columbia in spring 2001, it promised to revise the legal provisions for private sector education with the objective of expanding and facilitating private sector post-secondary education both for vocational training and degree study.

The Private Career Training Institutions Act, passed the legislature in the spring of 2003, abolished the Private Post-Secondary Education Commission (PPSEC), a government agency which had been created in 1992 by the Private Post-Secondary Education Act. PPSEC had the mandate of registering all private post-secondary institutions (but not Trinity Western University) and providing some basic "consumer" protection to students enrolled in these. Through the new legislation, PPSEC is being replaced with a new regulatory body (the Private Career 
Training Institution Agency [PCTIA]). The new agency will no longer receive any public funding, but will be entirely financed and controlled by the private education industry. Also, under the new legislation, no longer do all private training institutions come under the auspices of PCTIA as, under the new Act, only "career-related" training establishments are requested to register. This exempts the many English language schools in the Lower Mainland, which cater to foreign students, from any control and leaves students in these schools without any specific protection regarding their fees, if the institutions do not deliver what they had advertised. Also exempted from registering with PCTIA are all schools that offer short (defined as up to 40 hours in duration) courses or programmes.

\section{Private degree granting institutions}

Like most other provinces in Canada, British Columbia had until recently maintained the public monopoly over degree-granting institutions and programmes. In this respect, Canada has differed significantly from many other nations, for example the USA, Japan, Korea, and the Latin American countries where private, or non-public, institutions are playing a major role in providing both degree and non-degree programmes. This sole reliance on public higher education came to an end when a new Liberal government, elected in spring 2001, introduced legislation allowing and encouraging a private degree-granting sector.

Despite the significant increases in capacity and efficiency of the public sector in higher education over the 1990s, the capacity of the public system to accommodate the demand for degree studies is still limited, and the cost of its further expansion to meet the demand increasingly politically problematic. Taking advantage of barriers to participation in public college and university studies, private providers of distant degree programmes from the USA are aggressively recruiting students from British Columbia (and Canada as a whole). They are competing with Canadian public institutions on the basis of lower admission requirements, special programmes geared towards employability and workplace relevance, as well as alternative 
methods of delivery aimed at facilitating participation from specific groups, especially working adults. Examples are the Western Governors' University, the San Diego State University, and the University of Phoenix - the latter having recently set up operations in British Columbia.

From the mid-1980s, there had been one private degree-granting university in British Columbia, ${ }^{5}$ Trinity Western University (TWU), a liberal arts institution with strong ties to the Evangelical Free Church. As TWU is a member of the AUCC, its graduates are accepted by all public universities in Canada for advanced study programmes. Plans to start another private university in the Lower Mainland are well under way and the new Sea-to-Sky University will start admitting students for the autumn of 2005. Unlike TWU, this new university will be non-religious and cater to well-to-do, up-scale, full-time residential students. ${ }^{6}$

Together with the Private Career Training Institutions Act, the legislature passed a new Degree Authorization Act in early 2003, which regulates higher education. The new law provides the basis in law for private and out-of-province public institutions to grant degrees legally in British Columbia and to use the term "university" in their names. The new law provides for a Degree Quality Assessment Board with the mandate of reviewing applications from private and out-of-province public postsecondary institutions wanting to offer degree programmes in British Columbia, either as a university or under any other institutional title. After review of the proposals, with posting of the proposal on the Ministry web site, peer review, and, if the Board deems it necessary, a report by external experts, the Board makes recommendations to the Minister on whether the degree should be approved or refused. ${ }^{7}$

Although the new Act does not apply to public post-secondary institutions, the Ministry requires new degree programme proposals also to be reviewed by the Board thus replacing the Degree Programme Review Committee that had been set up earlier with the objective of assessing the academic quality of proposed programmes with regard to the appropriateness of the curricular content and methodologies to merit a "degree" status. 
The Board has eleven voting members, five from business and the private post-secondary education sector, four from the public postsecondary sector, and the remaining two members being a student representative and a representative of "the general public." Unlike the PCTIA, the Board is publicly financed. The terms of reference of the Board are to be "informed by government priorities" which are specified by four policy objectives, namely "increasing learner choice, ensuring quality..., promoting a coherent and integrated post-secondary system, and 'promoting the protection of learners' interests and ensuring appropriate use of publicly funded student financial assistance" (Ministry of Advanced Education, 2004).

\section{The Impact of the Reforms}

The government's new policy and structures mean that the landscape of post-secondary education has changed more drastically at the turn of the 21 st century than it did when Access for All policy was implemented. Although that earlier policy expanded and diversified the public sector, the new policy has opened post-secondary education, not only to private providers, but to market forces and mechanisms generally. If the latter can satisfy the Degree Quality Assessment Board's criteria for variety, quality, and sustainability, private investors and companies can offer degree programmes and even establish private for-profit universities without any involvement of the legislature. With this new policy the virtual monopoly of public sector higher education has been effectively abolished and British Columbia's higher education system in the future will resemble more that of the United States than the traditional Canadian system. ${ }^{8}$ Public universities no longer have autonomy in decisions about their own degree programmes, since it is now a body with a possible majority of members from the private sector that decides on the acceptability of degrees proposed by public universities and colleges. ${ }^{9}$

Both new policies have had an impact on student access and choice. With the exception of a few very lucrative and sought-after programmes, 
such as the Master of Business Administration (MBA) degree, private sector offerings will complement, rather than compete with degree programmes at the public universities, institutes, and colleges. Judging from experience with on-line programmes from institutions based in the United States already operating in Canada, the "privates" will seek to offer niche programmes to people unable to enrol in traditional programmes. Thus, the competition will offer mainly low-cost programmes to students without traditional entrance qualifications, or those who prefer on-line or otherwise alternatively delivered programmes to traditional campus-based and workday-scheduled courses.

There is reason to think that, despite establishment of a quality assessment agency and procedure, at least some programmes will have low quality - as private for-profit companies must control cost (and therefore salaries for highly qualified instructors) in order to make a profit. Although there is evidence of such low quality offerings, the present British Columbia government and its supporters and voters believe programmes can be delivered by the private sector more efficiently and at the same level of quality as by public institutions.

The breaking of the monopoly of public higher education will affect public institutions. Already, motivated by the need to attract good students, faculty members, and funding from non-public sources, universities and colleges are embracing strategies designed to compete with other public institutions and increasingly, one can assume, also private. Examples of competition include "recruitment" of full-cost tuition international students, engagement in privately organized consortia to sell degree programmes in international markets, and commercialization of university research. As do universities in other parts of Canada, most British Columbia universities and colleges are already engaged in these practices. It is safe to predict that the opening up of higher education to private investors and market mechanisms will enhance and accelerate this development. 


\section{SUMMARY}

Over the past fifty years reform, revision and constant change have been characteristic of British Columbia's higher education system. This article has emphasized two features of reform. The first, characteristic especially of the past decade, is the priority placed upon access to programmes leading to a degree. The second, even more recent and more significant in its effects, is creation of a private higher education sector to complement and compete with the public sector. Both reforms had the declared objective of enhancing student choice by expanding degree opportunities.

The first of the two reforms sought to reach that objective by diversifying the institutional fabric of British Columbia's public system. It created more spaces for students in existing institutions, partly by forcing universities and colleges to rationalize their operations and to mobilize efficiency reserves (Schuetze \& Day, 2001). Moreover, it created a second type of qualification, the "applied" degree and gave institutes and colleges the right to offer such degrees, this breaking the monopoly of universities for degree-granting.

The second reform-opening up higher education to the marketallows private investors and companies to offer degree programmes in British Columbia. This reform which has just been implemented in 2004 has not yet accomplished the objective of creating more spaces for wouldbe students. Yet, it has already accomplished another objective, not so clearly stated in government documents, namely breaking the monopoly of public higher education and opening it to private entrepreneurs and investors. In this "move to the market" British Columbia is not alone, of course, as other provinces have made first steps in that direction, or will do so before long. 


\section{Notes}

'The University College of Cape Breton (Nova Scotia) was the only other institution which, although similar in name, is quite different with regard to both mandate and structure.

${ }^{2}$ Not surprisingly, there was some confusion in the media and the wider community as to what this new title actually implied. For example, whereas the policy of the Civil Service Commission of Canada refer to "a graduate of a recognized university," a "graduate of a recognized degree granting institution" might not be seen as equivalent.

${ }^{3}$ Another new university that had been founded in 1997, the Technical University of BC (TechBC), was closed down before it had started its full operation.

${ }^{4}$ It appears that this transformation is already under way. According to a recent report (Buchan, 2003) about research conducted by faculty in university colleges, the list of Canada Research Chairs and competitive grants from NSERC, SSHRC, and other funding agencies such as government and the private sector, is impressive.

${ }^{5}$ The Asia-Pacific University in Vancouver offers Associate degrees.

${ }^{6}$ The legal foundations for TWU and the Sea-to-Sky University have been two separate legislative Acts authorizing the establishment and operation of these private non-profit universities.

${ }^{7}$ In the case of proposals by private or out-of-province institutions, the Board also considers such factors as financial solidity of the institution.

${ }^{8}$ Of course, it will take some time to evolve. By Spring 2004, there were 16 applications for new degrees pending before the Board only six of which came from the private sector. So far, no application was pending for establishing another private university.

${ }^{9}$ The earlier Degree Programme Review Committee had only members from public institutions. 


\section{References}

Allen, R.C. (1996). The economic benefits of post-secondary education and training in British Columbia-An outcome assessment. Vancouver: The University of British Columbia (Centre for Research on Economic and Social Policy).

Association of Universities and Colleges of Canada. (2003). About AUCC: Membership eligibility. http://www.aucc.ca/publications/media/2002/index_e.html (retrieved from the web Dec 15, 2003)

Axelrod, P. (1995). Higher education in Canada and the United States: Exploring the roots of difference. Historical Studies in Education, 7(2), 141-175.

B.C. Ministry of Advanced Education. (1998). Degree granting authorization. http://www.aved.gov.bc.ca/degree-authorization/pandoopp/welcome.htm (retrieved from the March 1, 2004).

Buchan, R. (2003). University College of British Columbia Consortium. Presentation to the House of Commons Standing Committee Pre-Budget Consultations 2003. Unpublished Report.

Cameron, D.M. (1991). More than an academic question. Halifax: Institute for Research in Public Policy.

Council of Ontario Universities. (2000). Response to the minister regarding the consultation paper: Increasing degree opportunities for Ontarians. http://cou.on.ca (retrieved from the web Dec. 15, 2003).

Dennison, J.D. (1992). The university college idea: A critical analysis. The Canadian Journal of Higher Education, 22(1), 109-124.

Dennison, J.D., \& Gallagher, P. (1986). Canada's community colleges: A critical analysis. Vancouver: UBC Press.

Gallagher, P., \& Sweet, R. (1997). Intermediate skill development in British Columbia: Policy options for a post-industrial era. Canadian Journal of Higher Education, 27(2,3), 179-210.

Government of Canada, \& AUCC. (2002). Framework of agreed principles on federally funded university research. http://www.aucc.ca/publications/ media/2002/index_e.html (retrieved from the web Dec. 15, 2003).

Jones, G. (Ed.) (1997). Higher education in Canada: Different systems, different perspectives. New York: Garland Press.

Provincial Access Committee. (1988). Access to advanced education and job training in British Columbia-Report. Victoria. 
Schuetze, H.G. (2000). Higher education and lifelong learning in Canada: Reinterpreting the notions of 'traditional' and 'non-traditional students' in a 'knowledge society.' In H.G. Schuetze \& M. Slowey (Eds.), Higher education and lifelong learners: International perspectives on change, (pp. 127-144). London and New York: Routledge-Falmer.

Schuetze, H.G. (2002). Canadian universities and their changing environment: Consequences for academic governance and administration. In A. Arimoto (Ed.), University reforms and academic governance reconsidered, (pp. 81-100). Hiroshima: University of Hiroshima (Research Centre for Higher Education).

Schuetze, H.G., \& Day, W.L. (2001). Post - secondary education in British Columbia 1988-1998: The impact of policy and finance on access, participation and outcomes. Vancouver: The University of British Columbia (Centre for Policy Studies in Higher Education and Training).

Wynn, G. (1993). Walking the tightrope of compromise: Developing Arts degree programmes in new hybrid institutions. Unpublished Paper, Vancouver, B.C. 